\title{
Entre la composición y el castigo. \\ La actuación de las autoridades de la provincia de Buenos Aires frente a los robos cometidos por los indios amigos en la campaña (1832-1855)
}

por

\author{
María Laura Cutrera \\ Instituto de Historia Argentina y Americana Dr. Emilio Ravignani de la Facultad \\ de Filosofía y Letras de la Universidad de Buenos Aires. \\ Becaria postdoctoral del Consejo Nacional de Investigaciones \\ Científicas y Técnicas (CONICET)
}

El trabajo que presentamos se propone mostrar el impacto que tuvo la política porteña entre los indigenas a los que nos referimos atendiendo, especialmente, a los intentos de eliminar o regular los robos cometidos por aquellos. Así, estas páginas ponen en evidencia cómo se encontraron dos maneras de concebir y resolver un mismo problema. Si los indios amigos asociaban el robo a un daño que un miembro del grupo realizaba a otro y que, por lo tanto, requería de una reparación, las autoridades provinciales lo consideraban una infracción a la ley.

Palabras Clave: Juan Manuel de Rosas; autoridades provinciales; indios amigos; robos; castigo.

ANTECEDENTES HISTÓRICOS Y PUNTOS DE PARTIDA*

Desde sus comienzos, la conquista española en el sur del Río de la Plata se encontró con indígenas que ocupaban las vastas extensiones pampeanopatagónicas. Alternando relaciones armónicas y conflictivas, ambos mundos

* Todos los pueblos y lugares a los que aquí nos referimos cuentan con su correlato cartográfico al final del trabajo. 
fueron hallando modos de vincularse que hicieron posible una convivencia a veces tensa, pero no menos pacífica ni cotidiana ${ }^{1}$.

Durante la etapa virreinal, Buenos Aires protegía su campaña con un cordón permeable de fuertes y fortines que se había terminado en 1781 con la construcción de Melincué y Ranchos. Lo completaban Chascomús, Monte, Luján, Salto, Rojas, Lobos, Navarro, Areco y Mercedes. El Río Salado oficiaba como barrera natural entre indios e hispanocriollos y, entre éste y las guardias, se extendía una amplia «zona gris» en la que ambas sociedades vivían en relativa calma. Sin embargo, para entonces buena parte de la población hispanocriolla había comenzado a diseminarse sobre la campaña atravesando el curso de agua, para internarse en tierra aborigen a su propio riesgo y merced a las negociaciones que establecían con los indios. Casi como si el río desbordara, primero los asentamientos espontáneos y luego las fuerzas expedicionarias, fueron quitando espacio al indígena.

Fue así que desde mediados de la década de 1810 y durante gran parte del decenio siguiente, las agrupaciones nativas que habitaban el sur del actual territorio bonaerense se vieron asediadas por el avance de dos frentes simultáneos. Por un lado, el asentamiento en dicho territorio de pobladores criollos se venía consolidando desde fines del siglo XVIII ${ }^{2}$. Por otra parte, como consecuencia de la prolongación al este de la Cordillera de los Andes de los conflictos independentistas chilenos, tuvo lugar el ingreso de contingentes de esa procedencia que incluían tanto grupos realistas de indios, criollos, mestizos, soldados y bandoleros, como alianzas patriotas de similar composición, que los perseguían ${ }^{3}$. La presión por los recursos, principalmente el ganado, se sumó a las contiendas políticas de esos años, dando lugar a una seguidilla de malones y contraataques hacia y desde la frontera bonaerense que incrementaron el nivel de tensión e inestabilidad existente en la campaña ${ }^{4}$. Estas

\footnotetext{
${ }^{1}$ Sobre la política de la monarquía española en América durante la etapa señalada, véase Weber, 1998: 147-172; 2005. Para el caso del Río de la Plata, véase Néspolo, 2006.

2 Sobre los conflictos y la inestable situación de la frontera bonaerense a partir de mediados de la década de 1810, ver Bechis, 2001: 65-99. El mismo artículo fue publicado, también, en Bechis, 2008.

${ }^{3}$ Cuando hablamos de los conflictos independentistas chilenos, nos estamos refiriendo a la Guerra a Muerte. Sobre ésta puede verse Bechis, 1983. Sobre sus fases «cordillerana» y «pampeana», véase Villar y Jiménez, 2003: 123-171.

${ }_{4}$ Merecen destacarse, en este sentido, el malón de 1820 sobre el pueblo de Salto y las expediciones llevadas a cabo por las autoridades de Buenos Aires. Éstas tuvieron lugar en 1821, 1822 y 1823, bajo el mando del entonces gobernador Martín Rodríguez. Durante el transcurso de la última se fundó el fuerte Independencia (actual Tandil), materializando la ocupación oficial varias leguas al sur de la línea establecida durante el período colonial, y violando parte de lo dispuesto por el Tratado de Miraflores - importante acuerdo con la
} 
circunstancias obligaron a las autoridades porteñas a tener siempre en cuenta la existencia de vecinos sureños más o menos propensos a la negociación. A su vez, las parcialidades nativas se descubrieron atrapadas en un movimiento de tenazas desplegado desde el norte y el oeste.

Cuando en 1825, la guerra con Brasil hizo real la posibilidad de una invasión portuguesa en las costas meridionales de la provincia, la necesidad de ganar la buena voluntad de los indígenas se volvió impostergable. Fue así que primaron las intenciones de establecer algún tipo de acercamiento y acuerdo con ellos, y asegurar el espacio ocupado hacia el sur. En 1826, el gobernador Gregorio Las Heras comisionó al entonces comandante de milicias de campaña de la provincia, Juan Manuel de Rosas, para formalizar un tratado de paz, tranquilizar los ánimos y estudiar por dónde correría la nueva línea de frontera, tarea que compartió con Felipe Senillosa y Juan Lavalle (Comando en Jefe del Ejército-Dirección de Estudios Históricos, 1974). El resultado de la empresa fue el establecimiento de un acuerdo con los naturales, en el que se sentaron las bases de una política de paz tendiente a prolongarse durante casi treinta años, asociada comúnmente con el rosismo y popularizada como «Negocio Pacífico de Indios» ${ }^{5}$.

Además de la entrega periódica de ganado, objetos y «vicios» —yerba, tabaco y aguardiente, por ejemplo- - y la disposición de un tramado jerárquico de autoridades encargadas de la atención de aquellos, el Negocio Pacífico implicó el asentamiento de grandes contingentes indígenas al interior de la provincia, en las proximidades de los fuertes o dentro de las estancias, mantenidos con fondos del erario bonaerense ${ }^{6}$. Los grupos que respondían a la autoridad de los

población nativa - firmado el 7 de marzo de 1820. En él se disponía, entre otras cosas, que los criollos no avanzarían más allá de las últimas estancias, esto es, sólo un poco más al sur del río Salado.

${ }^{5}$ El «Negocio Pacífico de Indios» fue una elaborada, compleja y constante negociación que buscaba establecer y sostener una conveniente relación de «amistad» con los indígenas. Asumió formas concretas - como los parlamentos, las entregas de regalos y raciones, y la estructura de autoridades puesta en juego para el cuidado y vigilancia de los indios amigosque formaron parte misma de la dinámica del pacto. No obstante, sus traducciones materiales no deben opacar la dimensión intangible que las relaciones cotidianas implicaban y que configuraban la característica distintiva de este particular modo de hacer política. Para una visión más detallada de esta interpretación, véase Cutrera, 2009. Para otras interpretaciones, puede consultarse Ratto, 1994a; 1994b; 2003a; 2003b.

${ }^{6}$ Aunque no era nuevo que estos decidieran integrarse a la sociedad criolla y habitar en la campaña, lo inédito de la situación residía en la vastedad de la población incorporada entonces. Silvia Ratto, que ha estudiado minuciosamente el tema, construye dos categorías para distinguir a los indios que pactaban con el gobierno. La autora llama «indios amigos» a aquellos que - como señalamos arriba - se asentaron dentro del territorio provincial, prestaban servicios laborales y militares, y mantenían una relación personal con el gobernador, recibiendo 
caciques Juan Catriel, Juan Manuel Cachul y Venancio Coñuepan se instalaron mayoritariamente en establecimientos rurales de la campaña - muchos de los cuales eran propiedad de, o estaban administrados por Rosas- y fueron relocalizados en los fuertes fronterizos en agosto de 1832. A partir de entonces, y por razones de defensa de una ocupación criolla prolongada varias leguas hacia el sur, se situaron en las proximidades del cantón de Tapalqué y del fuerte San Serapio Mártir del Arroyo Azul. Con anterioridad otras parcialidades se habían ubicado en los alrededores del fuerte Independencia, respondiendo de forma inmediata a los caciques Anteguan, Maicá y Petí, seguidores también de Catriel y Cachul en tanto caciques mayores ${ }^{7}$. Quienes estaban con Venancio se establecieron junto a él, en las inmediaciones de Bahía Blanca. En torno al Fuerte 25 de Mayo se asentaron años después, algunos núcleos llegados del otro lado de los Andes - conocidos como boroganos - al mando de los caciques Caneullán y Guayquil. Los parciales del Jefe Santiago Llanquelén, a su vez, se instalaron en las cercanías del fuerte Federación.

En abril de 1829, Rosas asumió la gobernación de Buenos Aires después de que la provincia se viera inmersa en una violenta guerra civil ${ }^{8}$. El nuevo mandatario siguió la línea de acción que venía gestándose desde el gobierno

raciones mensuales para su sostenimiento. Llamó, en cambio, «indios aliados» a los grupos indígenas asentados en territorio no controlado por el gobierno provincial, que conservaron su autonomía política, pero que habían acordado una relación pacífica con éste. Y aunque prestaban y recibían auxilio militar, así como raciones enviadas por las autoridades, asegura la autora que no puede precisarse con claridad — en la medida en que tampoco era evidente para los actores - qué otro tipo de compromisos se esperaba de esta relación. Vale decir que en la documentación no aparece tal distinción, denominándose «amigos» a todos los indios que estuvieran en paz con el gobierno. Para citar sólo algunas obras fundamentales de la autora, véanse Ratto, 1994a, 1994b y 2003a.

7 Como ha demostrado Lidia Nacuzzi, la jerarquización de ciertos jefes sobre otros era una práctica que reconocía sus raíces en tiempos coloniales. La autora sostiene que desde entonces, se planteaba a los españoles la necesidad de tratar con un cacique por grupo, ya que ante la mirada europea el panorama político aborigen — con su existencia de tantos caciques como seguidores pudieran movilizar- debió ser muy confuso. Por eso fue común que aquellos otorgaran a determinados jefes, respetados por sus pares y su gente, un «poder extra»; esto es, atribuciones extraordinarias que, en última instancia, beneficiaban a los hispanocriollos. La razón, como afirma Nacuzzi, es que la relación de los blancos con los grupos nativos estuvo centrada casi exclusivamente en la figura de sus líderes. La categoría de «caciques mayores» no escapa a esta lógica, y fue utilizada por Rosas para facilitar la manipulación de la relación jefes-seguidores y de la autoridad ejercida por aquellos, en función de sus intereses. Se trataba de colocar a ciertos personajes importantes del mundo indígena a la cabeza de sus indios, de otros caciques amigos, y de los grupos hostiles que decidieran deponer su actitud y acercarse a pactar paces con el gobernador. Véase Nacuzzi, 2008: 75-95.

${ }^{8}$ Rosas ejerció su mandato entre 1829 y 1832, haciéndolo nuevamente en 1835 . A partir de entonces, fue sistemáticamente reelecto hasta su derrota final en la Batalla de Caseros (1852), 
de Las Heras, a la que fue precisando y uno de cuyos aspectos fundamentales es el que dio lugar a este trabajo.

En este contexto, una de sus preocupaciones centrales fue restablecer el orden en el mundo rural, un orden que se creía alcanzado durante la colonia y perdido después de la revolución ${ }^{9}$. Se trataba de disciplinar las prácticas de los habitantes rurales y los indios amigos no escaparon a este proyecto. Para esto el gobernador se valió de un dispositivo de autoridades que involucró al mismo Rosas en la cúspide; al comandante del fuerte de Monte y su amigo personal, Vicente González; a los comandantes de los fuertes rodeados de tolderías indígenas - Bernardo Echevarría en Tapalqué; Francisco Serantes, Manuel Capdevila y Pedro Rosas y Belgrano en Azul; Juan Aguilera y Pablo Muñoz en Tandil; Mariano García y José Seguí en Federación; Felipe Julianes en Fuerte de Mayo; y Francisco «Pancho» Sosa y Martiniano Rodríguez en Bahía Blanca-; y a los caciques mayores Catriel, Cachul y Venancio. En ellos se ataba el nudo local de la dominación.

Una cuestión tuvo particular relevancia para las autoridades bonaerenses: los robos cometidos por los indios amigos, especialmente de vacunos y yeguarizos. El poco respeto que los indígenas parecían tener por la propiedad semoviente de sus vecinos criollos se convertía en un problema acuciante. En este tipo de conductas y en las reacciones que tuvieron Rosas y sus hombres, centraremos nuestra atención.

Propondremos que en esta dinámica, las autoridades provinciales fueron apropiándose de una facultad propia de los jefes parentales indígenas: reparar la ofensa recibida por alguno de los miembros del grupo, ya fuera a través de una composición en bienes o animales, o por medio de un malón en venganza. Cuando Rosas y sus hombres buscaron la reparación del daño, irrumpieron en las prácticas nativas haciendo suya la facultad que tenían aquellos para disponer el monto y/o la modalidad con que hacerlo. Pero en otras ocasiones, principalmente cuando la víctima era un criollo, el agravio que debía subsanarse fue convertido en infracción a la ley y trocada la restitución por el castigo.

En efecto, sostendremos también que en este aspecto de la política rosista de subordinación de los indígenas al orden, se encontraron dos lógicas que entraron en conflictivo contacto, dos maneras distintas de concebir y regular un mismo hecho. Si los indios amigos asociaban el robo a un daño que un miembro del grupo realizaba a otro y que, por lo tanto, requería de una reparación, las

ante las tropas comandadas por Justo José de Urquiza. Sobre el levantamiento de 1829 puede consultarse González Bernaldo, 1989: 137-176. Y también Fradkin, 2008.

${ }^{9}$ Al respecto puede consultarse Myers, 1995. También Gelman, 2004: 27-44 y Salvatore, 2003 
autoridades provinciales lo consideraban una infracción a la ley. En el cruce prevaleció la lógica criolla. El «mal» mutó en «delito», dando lugar a una situación radicalmente diferente para los naturales. Debieron aprender, entonces, cuál era el significado del castigo a la usanza criolla y qué implicancias tenía.

Para dar cuenta de estas cuestiones intentaremos, primero, una aproximación al problema de los agravios y su reparación en las agrupaciones indígenas.

\section{El DAÑo DEBE REPARARSE EXACTAMENTE COMO SE HA PRODUCIDO. \\ O CÓMO SE CONCEBÍA Y REGULABA EL ROBO ENTRE LOS INDIOS}

En las sociedades indígenas de Pampa y Patagonia, los recursos estratégicos - el agua, los terrenos de pastoreo, los montes, la vida silvestre - eran de uso relativamente libre. Esto quiere decir que, aunque podían ser frecuentemente aprovechados por determinadas agrupaciones, no se impedía su usufructo a miembros de otras o de quienes lo necesitaran. No obstante, como sugiere Stanley Diamond, ello no implica que todo fuera poseído en común. Por el contrario, significa que los medios materiales esenciales para la supervivencia eran de fácil disponibilidad general, pero existía la propiedad individual o colectiva sobre ciertos bienes básicos: regalos u objetos elaborados por un individuo, bienes o animales cuyo empleo generalizado no era socialmente imprescindible, por ejemplo ${ }^{10}$. Las armas, algunos utensilios, las prendas de vestuario o adorno, ciertos elementos procedentes del mundo criollo - cuchillos, sombreros o insignias militares-, el o los caballos, podían ser de un individuo en particular. También los había en posesión de una familia, al alcance de sus miembros o de uso compartido entre ellos, como los rebaños o rodeos de ganado.

Existían, entonces, formas de adquisición o acceso a éstos que eran reprobadas. Nos estamos refiriendo a los robos, que solían generar problemas o rivalidades entre dos o más integrantes de una parcialidad. Sólo que cuando sucedía, el hecho no podía ser traducido en términos de infracción a una norma y resuelto a través de su penalización, del modo en que se practicaba entre los criollos. Aquello que en sociedades que disponen de un cuerpo de leyes

10 Diamond, 1974: 131. Numerosos estudios han dado cuenta de la invalidez de la noción de «comunismo primitivo» que sostiene la ausencia total de propiedad privada en las sociedades llamadas ágrafas. La separación de la propiedad colectiva-individual no es tan simple, presentándose casos en que se mezclan o predomina uno u otro tipo. Incluso en una misma sociedad, pueden darse distintos criterios de propiedad respecto a las diferentes categorías de bienes. Véase Carozzi, Maya y Magrassi, 1991: 143-144. 
escritas se define como tal, entre los indígenas que nos ocupan se concebía como el «daño» que un miembro del grupo realizaba a otro. Y si un individuo hacía mal a alguien, se ponía en juego la reparación del agravio y no el castigo. Santiago Avendaño sostiene que según los indios, «todo hombre que es ofendido en su persona, en su honor o en su hacienda, no precisa [según ellos] de otra justicia que la de su razón, que le dicta hasta qué grado debe llegar su cólera cuando se vea ofendido» ${ }^{11}$. A su vez, los miembros de la parentela de la víctima también se consideraban perjudicados y se solidarizaban con ella.

En efecto, la capacidad de gestionar la reparación del daño cometido pertenecía siempre a la familia y el cacique, que cuando intervenía lo hacía en calidad de pariente del damnificado, interponía su influencia para ayudar a éste y a los suyos a resarcirse del agravio sufrido. William Mc Cann apunta que cuando se presentaba un «delito», la parte ofendida visitaba a los caciques para exponerle sus agravios ${ }^{12}$. Ellos convocaban a un «consejo» donde el más anciano informaba la agresión ocasionada contra un integrante de su grupo familiar usando «expresiones hiperbólicas» e indicando qué satisfacción debía dársele, hasta que acababa por exhortar a la guerra a todos sus compañeros. Luego hablaban los demás, "cada uno a su turno», y si la mayoría acordaba con ésta, quedaba decidida. Al día siguiente, el ofendido se ponía al frente de las fuerzas ${ }^{13}$. En sentido similar y en base a la información recabada para el caso chileno que puede aplicarse al nuestro, Tomás Guevara Silva agrega que:

...cuando un hombre de una parcialidad ha asaltado i muerto a otro de un grupo distinto, le ha robado su mujer o sus animales o le ha hecho víctima de sus hechi-

${ }^{11}$ Santiago Avendaño vivía en el sur de Santa Fe cuando en 1842, a la edad de siete años, fue tomado cautivo por un malón ranquelino. Permaneció entre estas agrupaciones hasta 1849. El 1 de noviembre de ese año, tomó dos caballos y huyó rumbo a San Luis. De allí partió a Buenos Aires. En enero de 1850 pudo entrevistarse con Rosas. Dos años después, era nombrado «intérprete de la provincia» para las gestiones de paz entre el gobierno de Buenos Aires y los indígenas del sur. Desempeñó esa función hasta su muerte en 1874. En 1854 escribió sus memorias, donde lejos de realizar una autobiografía, relata sus averiguaciones y vivencias entre los indios. Véase Avendaño, 2000: 106. Nótese que nuestro informante alude a la noción de «ofensa» personal.

${ }^{12}$ Luego de una estancia previa en el Río de la Plata, el comerciante inglés William Mac Cann volvió a embarcar para Buenos Aires a comienzos de 1847, a donde arribó en marzo. Desde allí inició su viaje a caballo por parte del interior de la actual Argentina, visitando también Paraguay y Uruguay. Los fragmentos aquí utilizados fueron recabados durante esta travesía. Véase Mc Cann, 1985. El uso de la palabra «delito» obedece a que Mc Cann fue informado de las costumbres aborígenes por el Comandante de Tapalqué. La lengua indígena no tenía un vocablo equivalente a ese. Se empleaba la voz huerin (daño) para referirse al robo y hueñefe para hablar del ladrón.

${ }_{13}$ Mc Cann, 1985: 97. 
cerías, la tribu del ofendido toma las armas, porque en la pequeña sociedad familiar descrita, el perjuicio de uno de sus miembros afecta a todos. A los parientes les obliga estrictamente a la venganza ${ }^{14}$.

Sin embargo, para el período aquí trabajado la tendencia a subsanar la ofensa por medios bélicos había cedido lugar a la composición; a lo sumo, oscilaba en un arco que se dibujaba entre el malón y dicha posibilidad. Según la explicación tentada por Guevara Silva, la costumbre de saquear al victimario causaba profundos desórdenes y rivalidades entre los grupos, debilitando su cohesión y su fuerza para resistir al enemigo común. El ofendido quedaba, entonces, en condiciones de proceder a voluntad, y decidir por la acción armada o por la reparación cubierta con bienes y/o animales, optando casi siempre por la última posibilidad.

En este contexto, el robo era uno de los males más gravemente considerados por la sociedad indígena, y el daño producido se resarcía con la restitución aumentada según la calidad del ladrón, de sus parientes, o las circunstancias específicamente vinculadas al hecho. Si se trataba de un hurto pequeño, éste exigía reparación en idéntica cantidad de bienes que los robados: un animal menor u objeto cualquiera, del mismo modo que ha marcado Guevara Silva para el caso trasandino, «se pagaba con otro igual». Las fuentes que analizaremos en la próxima sección dan cuenta de que esta era la forma usada habitualmente por los indios amigos. Y si el hurto era cometido contra los españoles, se lo reputaba de empresa lícita y lucrativa.

14 Tomás Guevara Silva fue un historiador chileno que escribió entre 1890 y comienzos del siglo XX. Entrevistó araucanos que habían vivido los últimos años de la soberanía indígena y les pidió que recordaran a sus familias, sus costumbres y hábitos. Los resultados de sus investigaciones se plasmaron en obras como Historia de la civilización en Araucanía, Los araucanos en la guerra de la Independencia, y Folklore araucano. Su trabajo, Las últimas familias y costumbres araucanas, es un estudio bilingüe que permite a la vez, obtener información específica sobre los grupos indígenas en cuestión y apreciar las dificultades de nuestra lengua en captar conceptos de sociedades no estatales. Si bien se trata de datos registrados en la araucanía chilena, la importancia que había adquirido el proceso de araucanización para la época que estamos trabajando, permite suponer que estas costumbres serían muy similares. No obstante, sólo en algunas ocasiones recurriremos a Guevara Silva. Dado que su investigación es de fines del siglo XIX, utilizaremos los datos que proporciona únicamente cuando se condigan con aquellos que brindan las fuentes locales. Por proceso de araucanización nos referimos a una migración de indígenas provenientes del lado sur-occidental de la Cordillera hacia su vertiente sur-oriental (actualmente argentina). Ésta se desarrolló a través de infiltraciones constantes y sucesivas y fue acompañada por el desarrollo de mecanismos de adaptación, fusión y transferencias culturales desde y hacia las agrupaciones de Pampa y Patagonia. Agradezco a Martha Bechis haberme dado a conocer y facilitado la obra del autor. Véase Guevara Silva, 1898: 44. 
Señala Guevara Silva que la tendencia a reemplazar el malón por la restitución en bienes o animales había adquirido importancia en Chile desde el siglo XVIII, dada la presencia de funcionarios coloniales instalados entre los indígenas. Aunque en la pampa este desarrollo pudiera no ser tan temprano, sí es cierto que se acentuaría durante la centuria siguiente; sobre todo en nuestro período, cuando encontramos a los indios amigos situados en puntos próximos a las guardias y bajo el cuidado de las autoridades provinciales. Aunque para las querellas con individuos de otras parcialidades quedara en pie la posibilidad de recurrir al malón, hacia la mitad del siglo XIX los indígenas que nos ocupan se inclinaban más a la composición que a la venganza. Por este motivo, y al igual que en territorio trascordillerano, el malón fue cada vez menos sangriento, al punto de verificarse sin lanzas. «Había contusos, por lo común, pero no muertos», sugiere el historiador chileno. De este modo, cuando existió, el malón se tornó una concreción violenta de la restitución no hecha: "se convirtió así en un medio casi regular de arrebatar, mentun, o de obtener por la fuerza el pago de una deuda $\left.{ }^{15}\right\rangle$.

\section{LAS PRIMERAS ACTUACIONES DE LAS AUTORIDADES PROVINCIALES}

En 1832, cuando el asentamiento de los grupos de indios amigos en el nuevo sur estuvo orientado a proteger los espacios recién ocupados por la provincia, las autoridades bonaerenses comenzaron a preocuparse por los hábitos que se les habían tolerado hasta entonces. Se pretendía en primer término, que permanecieran quietos y reunidos en los parajes a los que habían sido destinados, para contribuir a su defensa. Pero además, el gobernador y sus hombres aspiraban a lograr que abandonaran, entre otras, la costumbre de robar en los establecimientos rurales. Se esperaba que recibieran sus raciones, cuidaran de ellas y maximizaran su aprovechamiento. Rosas sostenía que si los bienes enviados desde Buenos Aires no se regalaban ni desperdiciaban, los indios podrían vivir sin tener que carnear ganado ajeno. Para completar esta tarea, al tiempo que se entregaron «vicios» y animales, se procuró fomentar la agricultura.

El hecho no impidió que las reses y tropillas de los indígenas se mezclaran con otras que pertenecían a los hacendados o al estado, ni que se robaran vacas, ovejas y yeguas entre blancos e indios, y entre $s^{\prime}{ }^{16}$. Sostiene Ricardo

15 Ibidem, 1898: 51.

${ }^{16}$ En varias oportunidades la historiografía del mundo rural pampeano ha planteado la inexistencia de criterios fijos de propiedad, y la persistencia de robos, mezclas y matanzas de animales de otros. Según Jorge Gelman, la posibilidad de que los estancieros aprovecharan 
Salvatore que la frecuencia con que se daba el hurto de equinos y vacunos en nuestro período pudo resultar de las tensiones creadas por el poblamiento y la ocupación de nuevas tierras, aunque también de la acción del estado. Ello se hacía visible en la amplia variedad de marcas, así como en las dificultades que se presentaban a los vecinos para separar el ganado ${ }^{17}$. El mismo autor afirma que «la obligatoriedad de las marcaciones y guías, la apropiación por parte del ejército de los caballos sin marca (caballos patrias), el efecto de las campañas militares sobre el precio de caballos y yeguas, la creciente organización del mercado de la carne, restringen el acceso de los paisanos pobres a estos recursos (vacas y caballos), antes libres o públicos» ${ }^{18}$.

Rosas procuró limitar estas contravenciones, hasta entonces toleradas, mediante el uso de marcas, guías y papeles que «documentaran» la tenencia, transporte y comercio de animales. Ello produjo, en palabras del autor, una «verdadera criminalización de las costumbres»y, a la vez, la ampliación de la esfera de acción de las autoridades ${ }^{19}$. Al igual que entre la población criolla, si estos robos involucraban a los indios de algún modo, el gobierno no tenía una respuesta unívoca. Los hombres de Rosas no reaccionaban de la misma manera si el robo se producía entre los indígenas, si se robaba a uno de estos o si un indio se apropiaba de animales cuyo dueño era un cristiano. En este último caso, las implicancias y consecuencias del hecho tenían mayor alcance y profundidad que en los dos primeros.

El 15 de diciembre de 1834, Bernardo Echavarría escribía al gobernador Rosas que el cacique Reylef se había quejado ante él de que Cachul «le había traído siete vacas lecheras y se las había carneado estando él ausente». Según el Comandante de Tapalqué, Reylef era un hombre de mucho juicio y muy

plenamente sus bienes y propiedades chocaba con prácticas de vieja herencia colonial entre los pobladores de la campaña. Así, la caza de avestruces y nutrias en cualquier terreno, tanto como el recurso a la leña de los montes ubicados en tierras ajenas, la sustracción de animales - favorecida por la ausencia de alambrados - , las mezclas constantes de ganado, o su contracara, la invasión en tierras propias de animales ajenos, son circunstancias permanentes en la campaña de estos tiempos. Véase Gelman, 1998: 223-240. También sobre esta cuestión, véase Fradkin, 1990.

17 Salvatore afirma que los delitos más comunes en la campaña bonaerense del rosismo eran aquellos que se cometían contra el estado y la propiedad. Y aunque según él, la importancia de los segundos disminuiría por el incremento de los primeros, los robos acusarían mayor frecuencia entre los crímenes contra la propiedad. Un $70 \%$ de ellos tenía por objeto el ganado vacuno y caballar, así como los cueros; en menor medida, la ropa, los aperos de montar y las mercaderías. En todos los casos, se trataba de objetos fácilmente comercializables. Véase Salvatore, 2003: 211-212.

${ }_{18}$ Salvatore, 1993-94: 105-106; 2003: 204.

19 Salvatore, 1993-94: 106. 
laborioso. Tenía una chacra grande «de maíz, porotos, zapallo, papas y otra porción de cosas», y casi todos sus parciales trabajaban en Azul. Mientras que ningún vecino se quejaba de ellos, lo contrario sucedía con quienes seguían a Cachul ${ }^{20}$. Echevarría decidió informar de los hechos a Rosas y esperar su respuesta. Días después, el Comandante resolvía todo respetando cada una de sus órdenes: llamó a Cachul a su rancho y colocó un centinela retirado del mismo, indicándole que no dejase pasar a nadie. A solas con el cacique, convino con él en reintegrar al damnificado cuatro bueyes y tres vacas que serían enviadas desde Buenos Aires.

Como puede apreciarse, se dispuso manejar la situación en los términos en que los indios lo hacían habitualmente, estipulándose un monto de composición que el ladrón debía reintegrar al robado. Sin embargo, no debe dejar de notarse una diferencia: quien daría los animales en realidad, sería Rosas. Las autoridades criollas se hacían cargo de la reparación de un daño que en otras condiciones se hubiera resuelto entre los directamente implicados. Creemos que el gobernador pudo justificar su intervención apelando al vínculo de compadrazgo que tenía con el cacique mayor. Lo cierto es que quienes perdieron la posibilidad de intervenir en la resolución de los hechos fueron Cachul y los suyos.

Nos interesa remarcar también, la singularidad del caso. No encontramos hasta el momento más incidentes así resueltos en la documentación. Quizás su particularidad se vea claramente si lo contraponemos con otras situaciones de naturaleza semejante. Los caciques amigos Juan Yerbal y Martín Collinao se quejaron al Coronel Juan Aguilera — Jefe de la División de Exploración y Reserva situada al exterior del Salado, de la que formaban parte- que en una noche «les habían robado 37 caballos de su propiedad y que, según indicios que ellos tenían, los habían llevado a los lados de Tapalqué»». Acompañados por un sargento, Aguilera permitió que marcharan seis indios para aquel destino $\mathrm{y}$ «después de apersonarse al jefe del punto, campecheen e indaguen sobre sus caballos». De ello resultó que, según les informó Cayupán —uno de los jefes tapalquinos-, «los indios que vinieron de chasque de la indiada del cacique Callfucurá, en su regreso a sus tolderías, fueron de medianoche a las inmediaciones de los campamentos y se robaron los enunciados caballos, los cuales los habían mandado adelante antes de marchar ellos, por cuya razón los indios de Collinao y Juan, no han podido encontrarlos» ${ }^{21}$. El Jefe de la

${ }^{20}$ Carta de Bernardo Echevarría a Rosas, 15 de diciembre de 1834, Archivo General de la Nación (Argentina), en adelante AGN, Secretaría de Rosas, Sala X, 43-1-2.

21 Juan Callfucurá era un cacique cordillerano que arribó a la Pampa para asentarse definitivamente en ella alrededor de 1840. Existen distintas hipótesis sobre las causas de 
División les sugirió, entonces, que se presentaran a Pedro Rosas y Belgrano - «como encargado especial para entender con los caciques en general»preguntándole «lo que debían hacer». La respuesta fue que él pondría al tanto de los hechos al Cacique Mayor Catriel y a Rosas. Las autoridades criollas intervinieron, pero sin demasiado interés en recuperar los animales robados o resolver el conflicto ${ }^{22}$.

Años después, al indio Qurrunque le hurtaron una manada de caballos. Sospechando que se trataba de uno de los parciales de Callfucurá y con autorización de Gregorio Barragán -interinamente a cargo del cantón de Tapalqué-, el damnificado mandó a uno de los suyos a Salinas a fin de recuperarlos. El emisario regresó trayendo sólo diez animales y diciendo que el cacique había mandado avisar que «estos los ha quitado a un indio llamado Pisen y este tiene madre y tío en los indios de Juan Manuel Cachul y que éste debe pagar la manada que robó el sobrino». Decía Barragán a Pedro Rosas y Belgrano: "Yo no tomo medidas a este respecto hasta que él [Cachul] no determine». Así planteadas las cosas, Qurrunque sostenía que entonces sería el indio Cantru — «que así se llama el tío del ladrón»—, quien debía hacerse cargo de la restitución correspondiente. Lo cierto es que tampoco quedaba claro si el ladrón pertenecía a los toldos de Cachul, pues según Callfucurá «no han sido sus indios los que robaron dicha manada» ${ }^{23}$. No sabemos cómo terminó el asunto, pero lo trajimos a colación porque creemos que muestra cómo operaban los mecanismos de resarcimiento propios de la sociedad indígena, involucrando a los parientes en el hecho, y la modalidad de intervención que tuvieron las autoridades provinciales competentes. Se limitaron a informarse de las cosas, habilitar a los indios para que circularan de un punto a otro en pos de la solución del problema, pero no participaron de la misma.

Nos preguntamos, entonces, ¿por qué lo hicieron en la disputa abierta entre Cachul y Reylef? Como el primero se mostró conforme con lo dispuesto por

su llegada. Lo cierto es que pactó paces con Rosas, aunque conservando su autonomía. Se instaló en la zona de Salinas Grandes — sudoeste de la actual provincia de La Pampa - desde donde cuidaba el ingreso de grupos procedentes del sur y del oeste a las últimas poblaciones bonaerenses, controlaba un recurso apreciado por los indígenas, y un ambiente económico y un paso comercial estratégico. Gracias a la satisfactoria combinación de todos estos factores, Callfucurá extendió una red de relaciones que lo vinculaban incluso, con importantes grupos del lado chileno de la cordillera. Sobre este personaje pueden consultarse Bechis, 1999a. Ratto, 2007. De Jong, 2007. Para una biografía del mismo puede verse la obra clásica de Zeballos, 2007.

${ }^{22}$ Carta de Manuel Corbalán a Juan Aguilera, 15 de diciembre de 1841, AGN, Secretaría de Rosas, Sala X, 26-1-2.

${ }^{23}$ Carta de Gregorio Barragán a Pedro Rosas y Belgrano, 11 de julio de 1848, Archivo Histórico de la Provincia de Buenos Aires (AHPBA), Juzgado de Paz de Azul, 39-1-4. 
Rosas, el Comandante aprovechó para explicarle las razones de su interés en el arreglo del desacuerdo entre ambos. «Pues que de ello resultaba — decía Bernardo Echevarría - que los unitarios y los indios enemigos no dijeran que los amigos de VS estaban como perros y gatos, y Cachul me prometió hacerlo así, y me dio su palabra muchas veces» ${ }^{24}$. Dado que se trataba de dos jefes importantes y que el robo podía agregarse a otras tensiones existentes, era fundamental poner pronto remedio al distanciamiento entre ellos y evitar mostrar al enemigo - criollo o no- un frente fracturado.

El mismo tipo de arreglo tenía lugar cuando la víctima era un indio y el estafador un blanco. Tres años después del último suceso narrado, Cachul avisaba a Echevarría que sabía por el cacique Collinao «que en la estanzuela del estado existe un caballo robado que es de su propiedad y que dice se lo robaron de este punto orejano, que más sabe de otros caballos que de su propiedad están en dicha estanzuela». El comandante no tardó en avisar al gobernador, y éste permitió que al efecto pasase el indio Gregorio —que a decir del cacique conocía los animales_-, a registrar la caballada y retirar aquellos que encontrase de su propiedad. No obstante, Rosas no dejó el caso incompleto. Por medio de Manuel Corbalán, notificó a Echevarría que «también se han remitido las prendas de plata para la recomposición, lo que deben decir al cacique que todo se hará como se pide» ${ }^{25}$. Nótese que además del ganado robado, Rosas entregaría prendas de plata. Creemos que se trataba de aquello a que Guevara Silva llama «la restitución aumentada», que se aplicaba según la calidad del ladrón, sus parientes, o las circunstancias específicamente vinculadas al hecho. En este caso, la víctima era un cacique mayor, y el victimario las autoridades provinciales.

Sin embargo, también aquí éstas intervinieron de una manera particular, posiblemente por tratarse de un jefe importante. En otras oportunidades su participación fue menos protagónica o no benefició tanto al damnificado. El 28 de julio de 1839, Nicolás Granada informaba al Juez de Paz de Salto que «habiendo desertado de este campamento el soldado del cuerpo de la escolta del gobierno Tiburcio Ríos», agregó a ese «crimen» el de «robar nueve caballos de los indios, de los cuales cinco son del cacique Nicasio». En la misma nota, el jefe del campamento notificaba a Pedro Arze que el soldado conductor de la misma tenía instrucciones para explicarle «la clase y señas

${ }^{24}$ Carta de Echevarría a Rosas, 7 de enero de 1835, AGN, Secretaría de Rosas, Sala X, $25-1-4 .^{\mathrm{a}}$.

${ }_{25}$ Carta de Manuel Corbalán a Echevarría, 9 de noviembre de 1837, AGN, Secretaría de Rosas, Sala X, 25-5-1. 
de aquellos para que si es posible se logre la recaudación de ellos y la aprehensión del delincuente» ${ }^{26}$.

En suma, aunque las circunstancias planteadas involucraran indios y cristianos, para solucionar los problemas desatados se apeló sin más a la lógica indígena. Se trató el conflicto como un agravio, como un "daño» cometido contra otro que requería de la composición para ser resuelto. Sin embargo, ello no debe opacar una novedad fundamental: las autoridades criollas pasaron a intervenir como parte, en conflictos hasta el momento regulados dentro de las agrupaciones. De acuerdo a los datos hallados en las fuentes y aquí presentados, puede suponerse que participaron activamente - haciéndose cargo de la composición - cuando se puso en juego la buena relación entre, y con dos importantes caciques amigos, ya porque fuesen ellos las víctimas o porque se trataba de un pleito que podía tener implicancias estratégicamente arriesgadas para la política de frontera.

Las consecuencias de estas intervenciones tuvieron un alcance mayor cuando se trató de robos a los criollos. Como se verá, las autoridades actuaron directamente entonces.

SOBRE LA INCORPORACIÓN DE LAS NOCIONES DE DELITO Y CASTIGO ENTRE LOS INDIOS AMIGOS

En diciembre de 1831, antes del traslado de los indios amigos hacia Tapalqué y Azul, el gobierno porteño había decretado la contramarca de los cueros que remitieran a la capital quienes no fuesen sus propietarios. El hecho involucraba a los indígenas, porque intercambiaban pieles obtenidas del ganado recibido de ración con los pulperos del lugar ${ }^{27}$. Como indicaba el gobernador a González, llevaban los conductores de animales la marca del estado (letra E), para poder contraseñarlos claramente en el momento de su entrega. Aseguraba Rosas que «con esta operación todo cuero de animal que se les muera, encontrarán sin dificultad negociantes que se los compren, lo que sin este requisito será imposible, porque hace cinco meses que el gobierno ordenó que ni los cristianos ni los indios pudiesen vender cueros sin ser contramarcados; por lo que (...) nadie puede comprar cueros sin este requisito

${ }^{26}$ Carta de Nicolás Granada a Pedro Arze, 28 de julio de 1839, AGN, Secretaría de Rosas, Sala X, 25-7-3.

27 Carta de Santiago Salas a Juan Manuel de Rosas, 20 de marzo de 1832, AGN, Juzgado de Paz de Monte, Sala X, 21-3-5. 
sin exponerse a perderlos $\gg{ }^{28}$. En el mismo sentido, apunta Prudencio Arnold que cuando se daba a los indios amigos yeguas en pie a cuenta de raciones, se las marcaba en el anca con el número «3» - suponemos que Arnold interpreta de este modo la vocal indicada-, y los comerciantes que compraran cueros a los naturales sólo debían hacerlo si llevaban esta señal. De no ser así, se suponía que se trataba de animales robados y debían ser decomisados por las autoridades del fuerte ${ }^{29}$.

Pese a esto, los indígenas no habían dejado de tomar o carnear ganado ajeno. Entre otras halladas en la documentación, la queja de un oficial militar de Tandil era precisa al respecto. Felipe Pereyra decía a Rosas que «el 24 a la tarde se dejaron ver por este destino ocho indios pertenecientes al cacique Don Pedro Antuan, y a su regreso para sus toldos se arrearon una tropilla de caballos de los que tiene a su cargo el Comandante Don Juan Aguilera» ${ }^{30}$. Pese a conocer a los responsables del hecho y encontrarse posteriormente que los animales estaban en sus tolderías, Pereyra y Aguilera no se animaron a tomar providencias para castigar el robo, pues supusieron que «se alborotarían los demás indios». Escribieron entonces al gobernador, y quedaron a la espera de indicaciones desde la capital ${ }^{31}$.

$\mathrm{La}$ frecuente reincidencia en conductas desaprobadas por las autoridades de la provincia a la que ahora pertenecían - y desde entonces vigiladas más atentamente-, determinó que los indios amigos tuvieran que aprender una serie de lecciones. La más importante de ellas se explicita en la nota de Pereyra. El comandante pidió instrucciones al gobernador sobre el castigo a dar a los culpables, y ello traía consigo la necesidad de asimilar dicha noción: ya

${ }^{28}$ Carta de Rosas a González, 16 de setiembre de 1832, AGN, Secretaría de Rosas, Sala X, 24-5-3. ${ }^{\mathrm{a}}$.

29 Prudencio Arnold nació en Buenos Aires en 1809. A los 17 años se incorporó como alférez al regimiento . $^{\circ} 3$ de milicias de campaña. Participó en la contienda que siguió al alzamiento de Lavalle, peleando en las batallas de Navarro y Las Vizcacheras. En 1833 se distinguió en la «Revolución de los Restauradores», ganando el grado de capitán. Fue ayudante de Vicente González cuando a comienzos de 1840, partió a Córdoba para enfrentar a las fuerzas de Lavalle. Pasó luego a desempeñar servicios en el Boquerón, cerca de Rosario, donde permaneció varios años protegiendo la frontera. Rosas lo ascendió a Coronel. Terminado su gobierno, decidió poner término a sus servicios. En cuanto al capítulo de su obra que refiere a Tapalqué, presenta el inconveniente de no estar situado en el tiempo. Disponemos de algunos datos que permiten ubicarlo cronológicamente en el resto del libro, pero parece atemporal. Sin embargo, por cotejo de datos que aparecen en las narraciones de Arnold con fuentes de archivo, creemos que su estancia en ese punto puede datarse hacia mediados de la década de 1830. Véase Prudencio Arnold, 1970: 98.

${ }^{3}$ Carta de Felipe Pereyra a Rosas, 31 de octubre de 1832, AGN, Secretaría de Rosas, Sala X, 24-7-3.

31 Idem. 
no había «reparación» posible, no se trataba de «componer» el daño hecho a otro, ahora se «castigaba» a un «culpable». Y si aparecía el castigo y, junto a él, la noción de culpa, surgía también la idea de «infracción». La infracción se hacía posible ante la existencia de una ley que se vulneraba, y ameritaba una sanción que ponía en práctica un dispositivo de autoridades con potestad de aplicarla.

Dos años después de estos hechos, el Comandante de Azul hacía presente su reclamo, pero arriesgaba también una forma de solucionar el problema. Decía a su par tapalquino, y éste al gobernador, que Francisco Serantes protestaba por tener que devolverle a los indios muchos de los cueros que traían para la venta. Las dificultades cotidianas se presentaban porque las más de las veces, las pieles no poseían la requerida letra «E», «ya que están mal marcados, o por mal pintadas las marcas o porque son realmente de animales robados, pues hasta cueros de caballos patrios han traído» ${ }^{32}$. Para remediar los hechos proponía poner en Tapalqué una marca a cada cuero de raciones, y la otra en Azul, a fin de que pudieran venderse y se evitase de este modo, «que en adelante vengan cueros que no estén en el registro de marcas y, por consiguiente, mal habidos $\rangle^{33}$. Las sugerencias de Serantes cayeron en saco roto. Los indígenas siguieron tomando animales ajenos. Prudencio Arnold afirma que «en las prácticas del robo, los indios carecían de cierto ingenio..., para ocultar los robos de hacienda que hacían en las fronteras, la marcaban también con ese número [el tres, al que ya nos referimos] pues los comerciantes que con ellos negociaban, no les compraban los cueros si no venían con esa marca, so pena de ser decomisados por las autoridades de los pueblos fronterizos» ${ }^{34}$. Los Comandantes se hicieron cargo, entonces, de la penalización de tales actos.

De su paso por Tapalqué, Arnold deja un relato sobre el castigo dado a un indígena que había carneado ganado patrio. Reproducir la narración viene al caso, porque permite arriesgar varias conclusiones.

Transcurrieron algunos días y un comerciante avisó que un indio traía un cuero sin la contramarca. En el acto, Echevarría lo hizo venir a su presencia, y averiguado el hecho resultó ser el cuero de un caballo patria que los indios habían comido. En castigo a ese delito, Echevarría lo mandó estaquear ordenando al mismo tiempo que arrollasen el cuero y se lo colocasen de manera que la nariz del indio quedase contigua a la marca del estado ${ }^{35}$.

${ }_{32}$ Carta de Echevarría a Rosas, s/f, AGN, Secretaría de Rosas, Sala X, 43-1-2.

${ }^{33}$ Idem.

${ }^{34}$ Arnold, 1970: 98.

35 Ibidem: 99. Según Charles Darwin, el estaqueo es un castigo muy común entre los blancos, severísimo, consistente en clavar en tierra cuatro postes y atar a ellos la víctima por los brazos y las piernas y, tendida horizontalmente, dejarla permanecer en esas condiciones por 
Algunas observaciones antes de continuar. Podríamos suponer que cuando se tratara de un robo de indígenas amigos a blancos, Echevarría debía informarlo a Catriel o Cachul, dada su condición de caciques mayores de las agrupaciones amigas. Podemos pensar además, que de imperar la lógica indígena, como ocurrió en los casos presentados en el apartado precedente, éstos debían averiguar qué indios resultaban culpables del hecho y la comunidad consultada tendría que «componer» el daño con una «restitución aumentada de lo robado». Sin embargo, es posible formular una pregunta: ¿cómo hacer para restituir lo robado tratándose de un bien que comienza a escasear, que presenta dificultades de apropiación, tenencia y tráfico, a lo que se ha sumado que se trata de indios «relocalizados», alejados de sus antiguos campos y de sus viejas prácticas de pastoreo?

Un segundo elemento a señalar es que Echevarría, al disponer a su arbitrio la pena a aplicar, pasó por alto la autoridad del cacique frente a sus seguidores. Ese traspié podía ocasionarle algunos inconvenientes, puesto que Rosas reconocía la importancia de la posición cacical para con los suyos y él, al no consultar con Catriel o Cachul, podía exponerse a un severo cuestionamiento por parte de éstos y de aquel. En directa relación con lo apuntado, se encuentra el inapropiado castigo dispuesto por el Comandante de Tapalqué. Reiteramos: los indígenas en cuestión podrían haber esperado que se pidiese la restitución de los bienes al grupo de parientes del ladrón. Pero sigamos otra vez a Prudencio Arnold.

...Cuando yo oí la orden, dije a Echevarría:

- No haga esa barbaridad mandando estaquear a ese indio.

-No han de hacer nada — replicó, refiriéndose a represalias que los salvajes pudieran cometer.

— ¿Y con qué nos vamos a defender si se enojan? - le dije.

— Voy a avisar a Catriel — repuso- y decirle que si no castiga a ese indio ladrón, el Restaurador se va a disgustar, y usted verá lo que lo respetan ${ }^{36}$.

Arnold entendió perfectamente los peligros que encerraba el accionar de Echevarría. Cuando solicitó al comandante «no haga esa barbaridad mandando estaquear a ese indio», comprendió que los indígenas podían enojarse porque Catriel no fue consultado, porque la forma utilizada no permitió la puesta en práctica de los mecanismos de reparación propios de los grupos indígenas, o

varias horas. El naturalista británico agrega que la idea está tomada del procedimiento empleado para secar pieles. Salvatore completa la descripción sugiriendo que el cuerpo era tendido cerca del suelo, y dejado así hasta que las tiras de cuero que amarraban cada uno de los miembros, se secaran y rompieran con el calor del sol. Véanse Darwin, 2000: 91. Salvatore, 2003: 246.

${ }^{36}$ Arnold, 1970: 99. 
por ambas cosas a la vez. Iban a vivirlo como una agresión y era esperable que reaccionaran a ella. Luego sucedió algo curioso: el Comandante decidió avisarle a Catriel «que castigue a ese indio», hecho que no iba a ocurrir porque los caciques no tenían la facultad de hacer uso de la fuerza sobre alguno de sus parciales ${ }^{37}$. Volvamos al curso del relato.

Mientras Echevarría volvió, se corrió la voz por las tolderías y empezaron a venir indios de todas partes y rodearon al estaqueado, juntándose en gran número. Cuando el cacique aprobó el proceder de Echevarría, pude yo respirar con libertad.

Echevarría me decía: "Yo trabajo con Catriel, porque dejen o modifiquen esa ley bárbara de matar sin compasión a todos los que por decreto de un bruto, se le ocurra decir que tiene gualichu»; pues esta preocupación, como he dicho, tenía propensiones a manifestarse también con la cuestión del estaqueo.

Los indios, mientras tanto, se ocupaban de rodear al estaqueado, de mojarlo y de reírse de él ${ }^{38}$.

Es sensible la intranquilidad de Arnold: los indígenas que se agrupan expectantes y la espera de la decisión del cacique frente a una determinación que ya había sido, en principio, tomada por Echevarría. Llama la atención, sin embargo, que Catriel apruebe el proceder del Comandante, y sin concurrir al espectáculo que se ocupará de montar; pero aún más, que los indios comiencen a participar del acto. A su vez, Echevarría comentó a nuestro informante que la elección de la pena se vinculaba con sus intentos de convencer al cacique para que abandonasen una antigua práctica que las autoridades criollas se habían propuesto desterrar. Entre aquellos el estaqueo era utilizado para vengar un asesinato provocado por hechicería, a eso se refería el Comandante cuando mencionaba al gualicho. A través de este procedimiento, Echevarría quiso lograr una traducción efectiva que operando desde la idea de la «gravedad del daño», estableciera «un vínculo estrecho entre la falta y la pena» que él estaba aplicando. Probablemente el comandante haya tratado de crear la equivalencia «delito = castigo», y para ello recurrió a un procedimiento asociado directamente al mal entre los indígenas. Aunque esto no es todo, el comandante hizo más.

Movido por un sentimiento de compasión manifesté a Echevarría que cuándo sacaba al indio de ese suplicio. Echevarría me contestó: «Ahora verá lo que voy a hacer». Seguidamente ordenó lo sacasen de la estaca, que hiciesen un agujero en el medio del cuero y se lo pusiesen a manera de poncho y lo corriesen a latigazos ${ }^{39}$.

37 Sobre las características de los liderazgos en Pampa y Araucanía pueden verse Bechis, 1999b. Cutrera y Morrone, 2009: 221-250. Néspolo, Cutrera y Morrone, 2009: 83-100. Para interpretaciones alternativas, puede verse Mandrini, 1992; 2000.

38 Arnold, 1970: 99.

${ }^{39}$ Idem. 
El Comandante modificó la pena a aplicar y ahora el castigo fueron los azotes. Sin embargo, Echevarría logró salir del lugar de tensión en que lo había colocado la toma de una decisión que no contó, en principio, con la anuencia del cacique, convirtiendo el hecho en un espectáculo del que empezó a participar la muchedumbre.

Cuando el indio comenzó a correr acosado por los rebencazos, que retumbaban en el cuero, sin que le marcasen las carnes, los espectadores prorrumpían en risa y golpeteos de boca. A medida que el indio huía, pisaba las puntas del cuero que casi arrastraban y se caía al suelo; se levantaba en seguida para volver a caer, perseguido siempre por el látigo, alarmando los caballos de los jinetes, que con todo esto aumentan el ruido y la gritería. Después de un rato, concluyó esta escena semisalvaje ${ }^{40}$.

Algunas reflexiones preliminares. Si con la pena del estaqueo el Comandante pretendía lograr una asociación entre «falta» — para los indios, un daño- y «castigo», a la vez que crear ambas nociones entre quienes las desconocían, el nivel de tensión generado lo condujo a dar a aviso de sus actos a Catriel y cambiar de táctica rápidamente. El uso de los azotes convirtió el caso en un espectáculo en el cual los propios indígenas también intervinieron. Según Salvatore, los azotes se aplicaban en la campaña para castigar delitos menores: una primera falta, la desobediencia en un soldado o la huida de un esclavo ${ }^{41}$. El hecho de que Echevarría hubiera decidido colocar el cuero al indio a la manera de un poncho y golpearlo sobre él sin marcar su piel, pone de relieve las intenciones del comandante: era menos importante generar sufrimiento corporal que desplegar el potencial visible de la pena.

Del contexto creado, Echevarría podía esperar varios efectos. Por un lado, el arrepentimiento del castigado, la intimidación, y el aprendizaje de éste y los asistentes. La convocatoria al resto de los indios a participar del acto reposaba en la convicción del poder transformativo del castigo para el punido y el observadorparticipante ${ }^{42}$. Por otra parte, quienes se habían acercado a presenciar el estaqueo ahora eran convidados a sumarse a la ejecución de la sanción. Es claro que el comandante no recurrió a ello inocentemente: si la invitación al resto de los indios tenía como meta última el aprendizaje, también procuraba la legitimidad del acto. El cacique no estaba brindando su anuencia, pero los indígenas avalaban el proceder de Echevarría. Fueron llamados como testigos, como actores y como fiadores de un hecho que devolvía, en contrapartida, una lección.

40 Idem.

41 Salvatore, 2003: 237.

42 Salvatore sostiene que la visibilidad de la pena posibilita el aumento de la productividad social de ésta, diseminando mensajes sobre la ley y la patria entre varias comunidades de espectadores: paisanos, soldados, milicianos, mujeres, indígenas y unitarios. Salvatore, 2003: 237-238. 
Por último, y al tiempo que generaba el impacto descrito, la escena ponía en evidencia un desequilibrio de fuerzas. A través de la elección y disposición arbitraria del fustigamiento y de convidar al resto de los aborígenes, el comandante hacía una demostración de violencia que se creía necesaria para intimidar a los indígenas que se quería sujetar al orden. Echevarría desplegaba la pretendida existencia de una desigualdad entre las autoridades provinciales y los indios amigos. Arnold pareció entender la necesidad de hacerlo y los peligros que entrañaba la acción cuando preguntó: «¿y con qué nos vamos a defender si se enojan?». Si al momento de producirse la incorporación de aquellos al territorio de la provincia, la sociedad indígena tendía a la conmutación del malón justiciero por la restitución, su par criolla experimentaba la concentración de la fuerza física legítima en un polo que se arrogaba la capacidad de ejercerla, viraba hacia la desproporción.

En el encuentro de estas dos situaciones, los indios debieron aprender las ideas de delito y castigo, a la vez que dejar en manos de las autoridades blancas la facultad de vengar - sin reparar - los daños cometidos. Cuando un indígena robaba a un cristiano, el «daño» mutaba en «falta» y en esa transformación, las agrupaciones de indios amigos — en particular los hombres jefes de familiase veían expropiadas de su capacidad de vengar los daños cometidos por sus miembros. Y decimos vengar porque, en efecto, detrás del espectáculo punitivo montado por Echevarría funcionaban las fuerzas oscuras de la vindicta ${ }^{43}$.

Tiempo después, los pulperos de Tandil se quejaron a Pablo Muñoz - el comandante-, de que «algunos indios mocetones, malentretenidos y sin ocupación alguna» robaban caballos, yeguas y potros a los vecinos e indígenas situados en las inmediaciones de la fortaleza, para luego intentar ubicarlos entre los comerciantes que hicieron la denuncia. Muñoz lo puso en conocimiento del gobernador, y se dio a la tarea de ingeniar un plan para «cortar este mal» por el que repetidas veces se habían quejado los primeros al comandante ${ }^{44}$. Había dispuesto entonces:

Que todas las yeguas que se traigan a esta fortaleza para el reparto de indios deben venir con los certificados de los respectivos dueños que las han vendido.

En segundo hacer una revisación de todos los cueros al tiempo de cargarlos para remitirlos a Buenos Aires y los que se encuentren que no sean con las marcas de los mismos certificados embargarlos y quedar detenidos hasta la resolución de SE. Amás de estas medidas está prohibido que ningún pulpero proceda comprar

\footnotetext{
${ }^{43}$ Aunque con notables diferencias y atendiendo a las particularidades del caso, el razonamiento sigue las reflexiones de Foucault, 2004: 54.

${ }^{44}$ Carta de Pablo Muñoz a Manuel Corbalán, 14 de febrero de 1838, AGN, Secretaría de Rosas, Sala X, 25-6-1.
} 
un solo cuero de noche a los indios aunque estos digan que son de ración por considerarse sospechoso el venderlos de noche ${ }^{45}$.

Rosas estuvo de acuerdo con la disposición de impedir la venta nocturna de cueros, y aprovechó para reprender duramente al comandante de Tandil, porque

la revisión general de todos los cueros al tiempo de cargarlos para remitirlos a esta ciudad (...), ha debido hacerse para darle la guía al conductor de todo lo que conduzca (y por lo que respecta a cueros de todas especies con las marcas pintadas en el centro según la orden vigente, y lo ordenado por punto general) ${ }^{46}$.

$\mathrm{Y}$ aun en caso de no haber sido así, tampoco se impedía con esta medida, que los indios siguieran robando. Decía el gobernador que

en tal estado la comandancia conservará en su archivo los certificados con las marcas. Se entregarán las raciones, venderán los indios los cueros, llegará el día del reconocimiento, se embargarán los que no estén conformes ¿y cuál será la certeza que tendrá entonces la comandancia de que esos cueros no son los de los animales dados de raciones? (...) y de todo ello resultaría que el comprador, pulpero o negociante vendría a perder el cuero comprado y embargado. Por otra parte, hay también que tener presente que los indios tienen animales que no son dados de ración, o que son procedentes de raciones antiguas y que con la medida indicada podrían toda vez que sacasen el cuero de algunos de esos animales, exponerse también a ser embargados ${ }^{47}$.

Aseguraba que por esta razón, y luego de mucho meditarlo, había dispuesto contramarcar las raciones con la letra del estado, por no hallar remedio más seguro. A ello agregaba ahora la opción de que los indios fueran teniendo sus propias marcas, «tanto más que con la del cabeza podrían marcar todos los indios de su dependencia, a cuyo efecto se les mandará las marcas que fuesen necesarias» ${ }^{48}$. Entonces Muñoz envió al gobernador una relación de los caciques y capitanejos que se hallaban en la fortaleza, y tuvo con ellos un parlamento «para evitar el robo de animales» e informar el asunto de las marcas. El tres de abril se remitieron cincuenta y dos marcas diferentes para los diez caciques y cuarenta y dos capitanejos existentes en Tandil. Las autoridades comenzaban así, a establecer en lo cotidiano la noción de pertenencia: el ganado marcado indicaba el dueño a que correspondía, y a esto se asociaba estrechamente la idea de falta implicada en el robo de lo que ahora podía ser

${ }^{45}$ Carta de Pablo Muñoz a Manuel Corbalán, 12 de marzo de 1838, AGN, Secretaría de Rosas, Sala X, 25-6-1.

${ }^{46}$ Carta de Manuel Corbalán a Pablo Muñoz, 17 de marzo de 1838, AGN, Secretaría de Rosas, Sala X, 25-6-1.

47 Idem.

${ }^{48}$ Idem. 
hallado con evidencias en manos del ladrón. También al acto de hurtar un animal ajeno el gobierno de la provincia colocaba una marca, que lo hacía trascender la idea de daño entre individuos o familias, convirtiéndolo en delito.

Esta práctica continuó realizándose pasado este momento y pensamos que posiblemente se haya extendido a los indígenas de otros puntos. Tiempo después, tres chinas se presentaron en la Comandancia de Tandil solicitando marcas para su ganado. Así que Rosendo Parejas les entregó «un boleto con la marca pintada, en que acreditaba tener derecho a ella (...) cuyas marcas se habían registrado en el archivo de esa Comandancia para que haya constancia de la donación» ${ }^{49}$.

Pero las penas y señales que debieron asimilar los indios amigos no fueron sólo visibles. La justicia rosista tenía, según Salvatore, una dimensión invisible, que el autor atribuye al nivel central de la misma, y que se sumó igualmente a las nuevas lecciones ${ }^{50}$. Aunque la situación carcelaria y los espacios transitados podían no diferenciarse demasiado de aquellos frecuentados cuando se era capturado en una acción bélica, los indios amigos que pasaban por ellos ya no estaban en guerra con el gobierno provincial. Posiblemente residiera aquí el verdadero aprendizaje de todo el potencial de violencia que eran capaces de desplegar las autoridades criollas: en principio, la celda no se oponía a la paz, pero al igual que para los blancos, el final de los aborígenes enviados a ella estaba muchas veces en el ejército de línea que, a diferencia de la milicia, se llenaba con voluntarios, enganchados o presos destinados ${ }^{51}$.

Los trayectos de prisioneros indígenas no distaban mucho de aquellos seguidos por los criollos enviados a la cárcel. Articuladas con la justicia ejercida en el plano local por los comandantes de los fuertes, las dependencias del Departamento Central de Policía — en particular la Cárcel Pública - eran, para los indios, aun más remotas y extrañas que para el común de la población blanca. En cada uno de los puntos fronterizos existía un cuarto utilizado a modo de celda, donde comenzaba el «movimiento de los cuerpos» de los indios amigos privados de la libertad hasta tanto se decidiera cómo castigar$\operatorname{los}^{52}$. Los actos que podían llevarlos a ello oscilaban entre la realización de faltas graves, la reincidencia en otras consideradas más leves, o simplemente la decisión del Comandante a cuyo cargo estaban. Permanecían en el calabozo durante un período habitualmente no muy prolongado, y se consultaba al

49 Carta del Edecán de Rosas a Rosendo Parejas, 25 de febrero de 1842, AGN, Secretaría de Rosas, Sala X, 26-3-1.

50 Salvatore, 2003: 241.

${ }^{51}$ Ibidem: 242.

52 Entrecomillamos la expresión empleada por Ricardo Salvatore para referir el tránsito de los presos por las distintas instancias del sistema carcelario del rosismo. Salvatore, 2003: 242-244. 
gobernador sobre la decisión a tomar. Rosas tenía la última palabra y podía ordenar al Comandante que pusiera al indio en libertad, o que lo remitiera a Buenos Aires «a disposición de SE». Cuando se era mandado a ésta, la prisión significaba el aislamiento, la distancia y lo desconocido.

Así, los indios Gueneque, Curruman, Naguelante y Antonio, estuvieron presos en la celda del Fuerte Independencia unos pocos días, por repetidos intentos de robo. El 1 de agosto de 1838, concretaron uno en la fortaleza en cuestión, y esa misma noche hicieron otro tanto en una pulpería del vecindario, perteneciente a Don José Arnol. De allí tomaron cuatro jergas, una copa de freno de plata, un fiador y diez pesos en el mismo metal, para lo cual abrieron «un portillo en dicha pulpería de noche con cuchillos»» ${ }^{53}$. Cuatro días después trataron de efectuar otros robos, «también de noche», en las tiendas de Don Guillermo Baudle y Don José Nogueira, pero «por haber sido sentidos no lo verificaron ${ }^{54}$. Sin mediar consulta a Rosas, por decisión de Pablo Muñoz fueron puestos a disposición del gobernador y remitidos a la capital. El veinticuatro de agosto Manuel Corbalán notificó al comandante de Tandil que los indígenas habían tenido entrada en la cárcel pública. Sabemos que el 19 de noviembre se envió a dos de ellos al ejército, al mando del General Don Servando Gómez, pero desconocemos quiénes, y a qué cuerpo o división se destinaron. Un mes después, los restantes fueron puestos bajo las órdenes del coronel Delgado, en el Escuadrón de Dragones.

También tuvo entrada en la cárcel pública el indio José María (o Chaná), por haber efectuado tres robos. En dos oportunidades quitó tropillas de caballos a dos vecinos de Tandil, Pedro Antonio Paz y Narciso Rivarola; a su vez, estando de peón de Juan José Gómez, «robó a este tres jergas, dos fajas, un lazo, un caballo y un chiripá de paño» ${ }^{55}$. Al parecer, José María no se ocupó o no tenía intenciones de deshacerse de los bienes y animales mal habidos, razón por la cual todos ellos fueron encontrados en su poder. Muñoz lo remitió con una prolija clasificación al Departamento de Policía, y tiempo después se le informó su ingreso en prisión. En diciembre del mismo año se presentó voluntariamente «para el servicio de las armas en el escuadrón de dragones de Buenos Aires que marcha al Entre Ríos», porque el gobernador les había ofrecido «si se portan bien darles las bajas honrosas luego de concluida la campaña» ${ }^{56}$.

53 Carta de Pablo Muñoz a Manuel Corbalán, 15 de agosto de 1838, AGN, Secretaría de Rosas, Sala X, 25-6-1.

${ }^{54}$ Idem.

${ }_{55}$ Carta de Pablo Muñoz a Manuel Corbalán, 28 de enero de 1839, AGN, Secretaría de Rosas, Sala X, 25-6-6.

${ }^{56}$ «Noticia de los individuos que se han presentado voluntariamente para el servicio de las armas en el escuadrón de dragones de Buenos Aires que marcha al Entre Ríos, y que el 
En los años que siguieron, la prisión continuó siendo el destino de aquellos que incurrían en prácticas delictivas, casi exclusivamente robos. Si bien se registran casos de homicidio en las fuentes, los delitos contra la propiedad -al igual que explican Salvatore y García Belsunce para los criollos- tenían protagonismo ${ }^{57}$. Pero además, el control de los robos en la campaña se puso al servicio de los intereses de una provincia cuya necesidad de hombres armados se hacía imperiosa ante los focos de conflicto que parecían abrirse con la década. Como sucedía entre los cristianos, los indígenas amigos que robaron y pasaron por las celdas, fueron destinados al ejército. El formato que debían cumplir las filiaciones da cuenta de ello ${ }^{58}$.

En los legajos de Juzgados de Paz, estas últimas, las notas de remisión y las listas de presos, comienzan a ser abundantes. Por sólo citar algunos casos, el indio Reglepán, que pertenecía «a la tribu del Cacique Mayor Catrie», fue enviado «por haber robado dos potros del Capitán Don José Antonio Preciado, y haberse arreado cuatro yeguas más ajenas del campo». Por idénticas razones y en las mismas condiciones, fue mandado Anuegual, que pertenecía también a la parcialidad Catriel ${ }^{59}$. Similar suerte tuvieron Juan Galván y su compañero Alpión, «por haber asesinado (...) al vecino de la Lobería Don Rafael Navarro, a su peón José María Reynaga y al chico hijo de éste, y después de este suceso robar la casa pulpería» ${ }^{60}$. José Claro y Manuel, entre tanto, fueron remitidos «asegurados con una barra de grillos cada uno con sus clasificaciones por duplicado por habérseles encontrado con 31 caballos y 41 yeguas robadas en el partido de la Lobería a varios vecinos, en la estancia del finado Don Rafael Navarro, tomados por el Sargento de esta división José Flores» ${ }^{61}$. Omar Carrupil, que no pertenecía «a ningún regimiento» y al igual que consta en

Exmo Gobernador de la Provincia les ha ofrecido si se portan bien darles las bajas honrosas luego de concluida la campaña», AGN, Secretaría de Rosas, Sala X, 25-7-1.

57 Véanse Salvatore, 1993-94 y García Belsunce, 1977.

58 A mediados de la década de los cuarenta, el modelo de filiación con que los Jueces de Paz de la campaña debían acompañar a los enviados a Buenos Aires se precisó y, entre los datos que la misma debía consignar, tenía que aclararse si el sujeto parecía «aparente para caballería o infantería» y qué servicios «hubiera prestado a la Santa Causa Nacional de la Federación», expresándose «los que tuviese desde el año de 1829 hasta la fecha». En caso de no haberlo hecho, "se expresará la causa por que no ha servido». Modelo de filiación circulado a los Jueces de Paz, s/f., AGN, Secretaría de Rosas, Sala X, 26-5-2.

${ }_{59}$ Ambas filiaciones son del 1 de noviembre de 1847 y se encuentran en AHPBA, Juzgado de Paz de Azul (1846-1847), 39-1-3. ${ }^{\mathrm{a}}$.

${ }^{60}$ Carta de Pedro Rosas y Belgrano a Antonino Reyes, 14 de febrero de 1848, AHPBA, Juzgado de Paz de Azul (1848-1849), 39-1-4.

${ }_{61}$ Carta de Pedro Rosas y Belgrano a Antonino Reyes, 18 de diciembre de 1848, AHPBA, Juzgado de Paz de Azul (1848-1849), 39-1-4. 
todas las filiaciones de indígenas, era «aparente para caballería», fue enviado «por ladrón incorregible y por salteador» ${ }^{62}$. A Ignacio Quiñigüel se lo mandó a Buenos Aires asegurado con una barra de grillos, con su clasificación y filiación por duplicado, «por haberse incorporado con los indios ladrones del caciquillo Quidañancú, que vinieron por los derrames de Tapalquén el 6 de abril del presente año». Lo mismo se hizo con Ramón Ancaguán, «por haber saltado la pared de la casa de Manuel Belgrano, y entrado a robar pillándose por los peones de la casa» ${ }^{63}$. En los partes cuatrimestrales del mismo Juzgado, Rosas y Belgrano informa que entre septiembre y diciembre de 1849, el indio Siriano Camapa «preso por ladrón y salteador incorregible fue remitido engrillado el 1 de octubre del corriente año al Cuartel General de los Santos Lugares de Rosas a disposición de SE». También Millagüeque, «preso por consentir en su toldo a indios ladrones ${ }^{64}$. A su vez, entre enero y abril de 1850, Marcelino Díaz fue enviado al mismo destino y en iguales condiciones, «con su clasificación y filiación por duplicado por haber robado una manada de yeguas al Señor General Don Prudencio Ortiz de Rosas y ser ladrón incorregible» ${ }^{65}$.

El único rasgo compartido por todos estos indígenas era su condición de indios amigos y la situación que parecía abrirse a partir de su incorporación al territorio y al orden provincial. Para los que conservaron su autonomía, las cosas no habían cambiado tanto. Cuando alguno de los que aún permanecían en «tierra adentro» era pillado robando y era tomado prisionero para ser remitido a Santos Lugares, muchas veces era dejado en libertad poco tiempo después. El Cacique Callfucurá, por ejemplo, se burlaba de ello ante un chasque de Catriel:

Que en las conversaciones que tuvo Callfucurá con su capitanejo [explicaba Gregorio Barragán a Rosas y Belgrano] le dijo que era en barro el que agarran algún indio de los ladrones y se los remitan a Ud. o a Catrie si luego lo habían de soltar (...) como ha sucedido con Necul que le ha mandado decir de los ranqueles que así que llegó a Buenos Aires el Sr. Gobernador lo largó para que se fuera y que lo hizo acompañar hasta cierta distancia y que esto el lo cree porque no podría escaparse un hombre que está seguro con marca de fierro que estas no se cortan con cuchillo ${ }^{66}$.

\footnotetext{
${ }^{62}$ Filiación del indio Omar Carrupil. Fuerte Azul, 1 de octubre de 1849, AHPBA, Juzgado de Paz de Azul (1848-1849), 39-1-4.

${ }^{63}$ Carta de Antonino Reyes a Pedro Rosas y Belgrano, 4 de septiembre de 1850, AGN, Juzgado de Paz de Azul, Sala X, 20-10-2.

${ }^{64}$ Parte cuatrimestre correspondiente a los meses de septiembre a diciembre de 1849, AGN, Juzgado de Paz de Azul, Sala X, 20-10-2.

${ }_{65}$ Parte cuatrimestre correspondiente a los meses de enero a abril de 1850, AGN, Juzgado de Paz de Azul, Sala X, 20-10-2.

${ }^{66}$ Carta de Gregorio Barragán a Pedro Rosas y Belgrano, 13 (no consta el mes) de 1848, AHPBA, Juzgado de Paz de Azul (1848-1849), 39-1-4.
} 
Quienes pactaron con Rosas y se instalaron dentro del territorio ocupado por la provincia, entretanto, debían adecuarse a los proyectos de la sociedad en que vivían y ello significaba aprender e incorporar nuevas nociones -el delito y el castigo - y sus signos - las marcas - . También se utilizaban otros procedimientos para sancionar conductas no aprobadas - el estaqueo, los azotes, la cárcel y el ejército-, así como para aceptar la presencia de encargados especiales en la aplicación de las sanciones - los comandantes de los fuertes, los jueces de paz, y los alcaldes y tenientes alcaldes, que desempeñaban funciones de policía-. El robo, un daño efectuado por un miembro de la agrupación contra otro, tenía ahora nuevas dimensiones e implicancias. Por eso afirmaba Avendaño que los indios

dicen que los cristianos tienen muy mal manejo en la política; que los comandantes castigan y proponen al gobierno el individuo al que le han echado el ojo, para que lo destine como soldado y que a cualquiera se le castiga, avergonzándolo con toda clase de bajezas y que el ofendido no puede vengar la ofensa que ha recibido, porque es la autoridad que ha cometido esta falta (...). Una de las costumbres más raras y que creen muy justa, es la de castigar o por mejor decir, la de hacerse juez y parte en la causa, pues dicen los indios que no hay cosa más satisfactoria entre los hombres que cuando un ofendido castiga al criminal por su propia mano, evitando así una definición que casi siempre cae al paladar del que aplica la sentencia, y así deja impune el hecho que podría castigarse con más rigor por la mano del ofendido. De allí el dicho que «para el indio la venganza es cosa sagrada» ${ }^{67}$.

\section{Consideraciones Finales}

Caído Rosas, los mecanismos aprendidos en casi un cuarto de siglo de subordinación a las autoridades de la provincia continuaron funcionando, y a veces más lubricadamente que antes. El sobrino del capitanejo Medina, por ejemplo, fue puesto en prisión por haber «llevado a Tandil un cuero (...) de la marca del indio Marín». Su tío se presentó al Comandante del punto solicitando la libertad del sobrino y acompañado del supuesto victimario para que éste aclarase que no le había sido robado, sino que se lo había dado por propia voluntad y mostrara el certificado de su marca. Resuelto el caso, desde Tapalqué se pidió a Pablo Muñoz - a cargo del Fuerte Independencia- que lo pusiera en libertad ${ }^{68}$. Meses después, un indio que salió de Bahía Blanca

\footnotetext{
${ }^{67}$ Avendaño, 2000: 106.

${ }^{68}$ Carta de José María Pereyra a Pablo Muñoz, 25 de noviembre de 1854, AHPBA, Juzgado de Paz de Azul (1852-1855), 39-1-6.
} 
se presentó en Tandil denunciando que Juan Bernal traía seis caballos robados que, se sabía positivamente, había vendido en Azul al vecino Juan Ángel Farías. Carlos Darragueira — Juez de Paz de Tandil— pedía a Ramón Vittón — su par de Azul— que se sirviera «echar justicia» ${ }^{69}$.

Al parecer habían aprendido a jugar siendo parte del engranaje montado. En el primero de los casos citados, pueden constatarse la perduración del sistema de marcas entre los indígenas, el registro de las mismas, y el conocimiento y uso apropiado de los modos de actuar y las autoridades a quienes recurrir. Esta última cuestión es visible también, en el segundo hecho relatado. Si ante el encierro de un indio en una celda, su tío se apersonó e hizo el reclamo correspondiente al Comandante, ante dos vecinos involucrados en el robo de caballos, el indio Juan supo que debía gestionarlo con el Juez de Paz. Podrá decirse, acaso, que se trata de prácticas mestizas y no negamos que pueda ser así. Pero creemos que ello no debe opacar el paulatino y conflictivo aprendizaje de la ley, de sus hombres, y de nuevas nociones entre los indios amigos. Porque sobre todo, fue un proceso lento y cuya complejidad puede incluso desvanecerse en apariencia, si únicamente ponemos el acento en la bidireccionalidad de las transferencias culturales.

Los robos cometidos en la campaña fueron una de las preocupaciones centrales en los intentos de disciplinamiento del mundo rural durante el rosismo. Se trataba de erradicar viejas prácticas y a este proceso no escapaban los indios amigos. Como se encontraban incorporados al territorio de la provincia, debieron ajustarse a las disposiciones y normas que el gobierno quisiera implantar en ella. El hecho dio lugar a un desafío de acomodamiento que acabaría teniendo repercusiones en sus costumbres.

En este trabajo nos ocupamos de analizar las formas de intervención de las autoridades provinciales ante los robos cometidos por aquellos. Y dijimos que en esta dinámica, las autoridades bonaerenses fueron apropiándose de una facultad propia de los jefes parentales indígenas: reparar la ofensa recibida por alguno de los miembros del grupo, ya fuera a través de una composición en bienes o animales, o por medio de un malón en venganza. Así, mostramos que cuando se trató de robos realizados entre indígenas o cuando el hurto efectuado por un criollo los tenía por destinatarios, Rosas y sus hombres buscaron subsanar el daño, e irrumpieron en las prácticas nativas haciendo suya la facultad que tenían los cabezas de familia para disponer el monto y/o la modalidad con que hacerlo. Mediando entre las partes $\mathrm{u}$ ofreciendo tomar a su cargo la composición, introdujeron una presencia exógena en la regulación

${ }^{69}$ Carta de Carlos Darragueira a Ramón Vittón, 21 de marzo de 1855, AHPBA, Juzgado de Paz de Azul (1852-1855), 39-1-6. 
de los conflictos. Pero cuando un indio quitaba algo a un criollo o al estado, el castigo era la única solución posible. Este hecho ponía en juego la incorporación y el aprendizaje de ciertas nociones por parte de los aborígenes: el delito, la punición y la existencia de autoridades específicamente destinadas a la aplicación de las sanciones. Se perdía, para ellos, la capacidad de intervenir en el resarcimiento del daño y la idea misma de composición, simplemente porque ya no había agravio por arreglar: ahora era un delito. En esos casos, planteamos, la lógica indígena de la «restitución» y la criolla de la «infracción a la ley» y el «castigo», se encontraron, y en el cruce prevaleció esta última.

En sus comienzos, los comandantes se privaron de aplicar cualquier tipo de penalización si no mediaba la consulta a Rosas. Tal fue lo ocurrido en Tandil. Pero ante la persistencia de prácticas aborígenes ahora definidas como delictivas, optaron por hacerse cargo de la facultad de punir esos actos. El relato de Arnold sobre el castigo dado por Bernardo Echevarría a un indio acusado de robar ganado patria en Tapalqué, da cuenta de ello. Señalamos también el fuerte énfasis que este militar puso en el carácter espectacular de la condena y la participación de la comunidad en él.

Luego apareció la prevención en su modalidad quizás más extrema: los indios amigos comenzarían a tener marcas propias. Esta disposición de Rosas reforzaba la construcción de las nociones de delito y crimen. Si la señal en el animal permitía identificar al indio portador de éste, que era inmediatamente presumido de ladrón, con ello se favorecía que el hecho trascendiera la idea del daño para alcanzar las dimensiones de una infracción que requería ser castigada.

Las marcas de los animales y algunas penas se externalizaron, pero existía también una cara invisible de la fuerza provincial que se manifestaba sobre los grupos amigos. Las dependencias del Departamento Central de Policía —en especial la Cárcel Pública - se sumaron también, a las nuevas ideas y espacios que debían ser aprendidos por los indios. Eran para ellos aún más remotas y extrañas que para los criollos. Y al igual que ocurría con éstos, desde allí los indígenas eran destinados la mayoría de las veces al ejército de línea.

Tomó varios años establecer los procedimientos y graduar los niveles de intervención que los Comandantes, encargados de policía y el mismo gobernador podían tener. Cuando todo parecía estar funcionando más o menos aceitadamente, una serie de acontecimientos —el adelantamiento del cantón de Tapalqué, las luchas políticas que tenían lugar entre Buenos Aires y la Confederación liderada por Urquiza, y el asesinato de un cacique amigo a manos de un teniente de Bahía Blanca - rompieron el todavía inestable equilibrio conseguido. Los indios amigos devinieron en enemigos, y nada volvió a ser como era. 


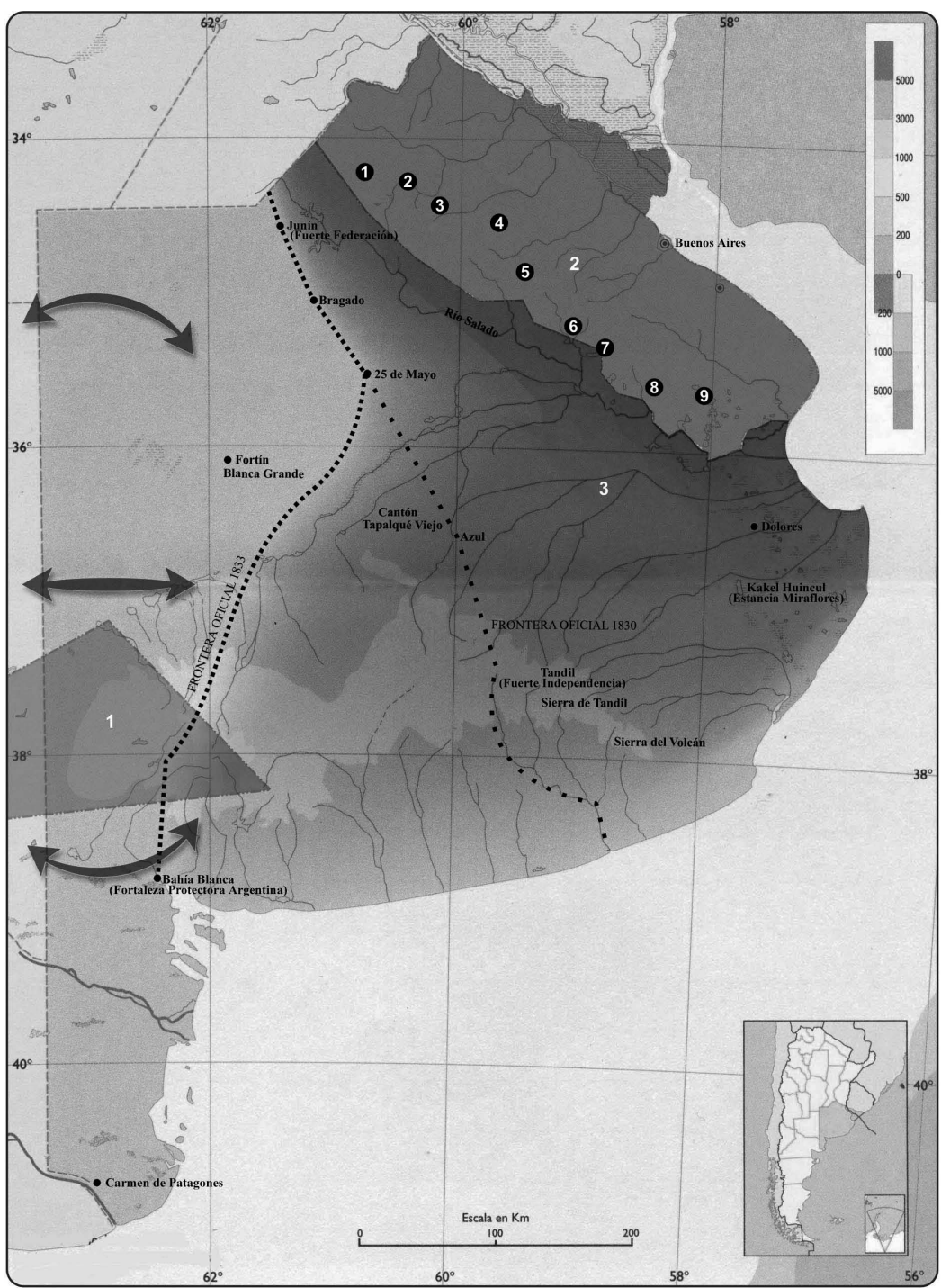

\section{Referencias}

Triángulo de campamentos centrales de los Pampas y Serranos hasta entrada la década de 1820: Sierra de la Ventana, Guaminí, Salinas Grandes (Sudoeste de la actual Pcia. de La Pampa)

Espacios ocupados por población criolla hasta 1820

Movimiento de Grupos Trasandinos hacia y desde las Pampas

3 Espacios ocupados por la provincia durante el período estudiado

$\begin{array}{ll}\text { (1) Rojas } & \text { 6 Lobos } \\ \text { (2) Salto } & \text { (7) Monte } \\ \text { (3) Guardia de Areco } & \mathbf{8} \text { Ranchos } \\ \text { (4) Guardia de Luján } & \text { 9 Chascomús } \\ \text { (5) Navarro } & \end{array}$




\section{BIBLIOGRAFÍA}

Ares Queija, Berta y Gruzinski, Serge (coords.), Entre dos mundos. Fronteras culturales y agentes mediadores, Sevilla, EEHA-CSIC, 1997.

Bechis, Martha, Interethnic relations during the period of nation-state formation in Chile and Argentina. From sovereing to ethnic, Ann Arbor Michigan, University Microfilms International, 1983.

Bechis, Martha, "La vida social de las biografías: el caso de la biografía de Juan Callfucurá, 'líder total' de una sociedad sin estado", Ruth Sautu (comp.), El método biográfico. La reconstrucción de la sociedad a partir del testimonio de los actores, Buenos Aires, Universidad de Belgrano, Editorial de Belgrano, 1999a.

Bechis, Martha, "Los lideratos del área arauco-pampeana. ¿Autoridad o poder?”, número especial de La etnohistoria en CD, Revista Naya (Buenos Aires, 1999b).

Bechis, Martha, "De hermanos a enemigos: los comienzos del conflicto entre los criollos republicanos y los aborígenes del área arauco-pampeana, 1814-1818", Susana O. Bandieri (coord.), Cruzando la Cordillera... La frontera argentinochilena como espacio social, Neuquén, CEHiR-UNCo, 2001: 65-99.

Bechis, Martha, Piezas de etnohistoria del sur sudamericano, Madrid, CSIC, 2008.

Boccara, Guillaume, "Etnogénesis mapuche: resistencia y reestructuración entre los indígenas del centro-sur de Chile (siglos XVI-XVIII)", Hispanic American Historical Review, 79/3 (Duke 2000): 425-461.

Carozzi, Blanca, Maya y Magrassi, Conceptos de antropología social, Buenos Aires, CEAL, 1991.

Comando en Jefe del Ejército (Dirección de Estudios Históricos), Política Seguida con el Aborigen, Buenos Aires, Biblioteca del Oficial, 1974, vol. 2.

Crivelli Montero, Eduardo, "Estacionalidad y sistema de asentamiento indígena en la pampa bonaerense durante la etapa ecuestre", ponencia presentada en las Primeras Jornadas de Investigadores en arqueología y etnohistoria del centro-oeste del país, Córdoba, Universidad Nacional de Río Cuarto, 1993.

Cutrera, María Laura, "La trama invisible del Negocio Pacífico. De cómo Rosas supo ser algo más que un cristiano amigo para los indios", Revista Tefros, VII/1 y 2 (Río Cuarto, Córdoba, 2009). http://www.unrc.edu.ar/publicar/tefros/revista/ v7n12d09/paquetes/cutrera.pdf consultada en abril de 2013.

Cutrera, María Laura y Morrone, Ariel, "Parentesco, autoridad cacical y subordinación al orden. Una revisión teórica e histórica de la política rosista hacia las parcialidades amigas de la región pampeana (Buenos Aires, 1829-1839)", Anuario de Estudios Americanos, 66/1 (Sevilla, 2009): 221-250.

De Jong, Ingrid, “Armado y desarmado de una confederación: el liderazgo de Callfucurá en el período de organización nacional”, El liderazgo indígena en los espacios 
fronterizos americanos (siglos XVIII y XIX), Buenos Aires, Museo Etnográfico Juan B. Ambrosetti, 2007.

De Jong, Ingrid y Rodríguez, Lorena, "Introducción” al dossier "Mestizaje, etnogénesis y Frontera", Memoria Americana, 13 (Buenos Aires, 2005): 9-19.

Diamond, Stanley, In search of the primitive. A critique of civilization, New Brunswick (New Jersey), Transaction Books, 1974.

Foucault, Michael, Vigilar y Castigar. Nacimiento de la prisión, Buenos Aires, Siglo XXI, 2004.

Fradkin, Raúl, "Entre la ley y la práctica. La costumbre en la campaña bonaerense de la primera mitad del siglo XIX", Anuario del IEHS, Universidad Nacional del Centro de la Provincia de Buenos Aires (Tandil, 1990): 141-156.

Fradkin, Raúl, Fusilaron a Dorrego, Buenos Aires, Sudamericana, 2008.

García Belsunce, César, Buenos Aires, salud y delito, Buenos Aires, Emecé, 1977, tomo II.

Gelman, Jorge, "Un gigante con pies de barro. Rosas y los pobladores de la campaña", Noemí Goldman y Ricardo Salvatore (comps.), Caudillismos Rioplatenses, Nuevas miradas a un viejo problema, Buenos Aires, Eudeba, 1998: 223-240.

Gelman, Jorge, "La construcción del orden postcolonial. El 'sistema de Rosas' en Buenos Aires, entre la coerción y el consenso", Tiempos de América, 11 (Madrid, 2004): 27-44.

González Bernaldo, Pilar, "El levantamiento de 1829: el imaginario social y sus implicaciones políticas en un conflicto rural", Anuario del IEHS, 3 (Tandil, 1989): 137-176.

Gruzinski, Serge, El pensamiento mestizo, Barcelona, Editorial Paidós, 2000.

Mandrini, Raúl, Los araucanos de la pampa en el siglo XIX, Buenos aires, CEAL, 1984.

Mandrini, Raúl, "Procesos de especialización regional en la economía indígena pampeana (siglos XVIII y XIX): el caso del suroeste bonaerense", Boletín Americanista, 41 (Barcelona, 1991): 113-137.

Mandrini, Raúl, "Pedir con vuelta ¿reciprocidad diferida o mecanismo de poder?", Antropológicas, nueva época, I/IIA (México D.F., 1992).

Mandrini, Raúl, “El viaje de la Fragata San Antonio, 1745-1746. Reflexiones sobre los procesos políticos, operados entre los indígenas pampeano-patagónicos", Revista Española de Antropología Americana, 30 (Madrid, 2000): 235-263.

Myers, Jorge, Orden y Virtud. El discurso republicano en el régimen rosista, Quilmes (Buenos Aires), Universidad Nacional de Quilmes, 1995.

Nacuzzi, Lidia, "Repensando y revisando el concepto de cacicazgo en las fronteras del sur de América (Pampa y Patagonia)", Revista Española de Antropología Americana, 38/2 (Madrid, 2008): 75-95. 
Nespolo, Eugenia, Resistencia y complementariedad, Gobernar en Buenos Aires. Luján en el siglo XVIII: un espacio políticamente concertado, tesis de doctorado en Historia, Facultad de Filosofía y Letras, Universidad de Buenos Aires, 2006.

Nespolo, Eugenia, Cutrera, María Laura y Morrone, Ariel, "El líder étnico, liderar y liderazgo. Los Yahatti, Lepin, Juan Manuel Cachul y Juan Catriel: hombres políticos en la frontera bonaerense", Revista Española de Antropología Americana, 39/2 (Madrid, 2009): 83-100.

Ratto, Silvia Mabel, "Indios amigos e indios aliados. Orígenes del Negocio Pacífico en la provincia de Buenos Aires (1829-1832)", Cuadernos del Instituto de Historia Argentina y Americana Dr. Emilio Ravignani, 5 (Buenos Aires, 1994a).

Ratto, Silvia Mabel, "El Negocio Pacífico de Indios: la frontera bonaerense durante el gobierno de Rosas”, Siglo XIX, 15 (México, 1994b).

Ratto, Silvia Mabel, "Una experiencia fronteriza exitosa: el Negocio Pacífico de Indios en la Provincia de Buenos Aires (1829-1852)", Revista de Indias, LXIII/227 (Madrid, 2003a): 191-222.

Ratto, Silvia Mabel, Estado, vecinos e indígenas en la conformación del espacio fronterizo. Buenos Aires, 1810-1852, tesis doctoral presentada en la Facultad de Filosofía y Letras de la Universidad de Buenos Aires, $2003 \mathrm{~b}$.

Ratto, Silvia Mabel, "Tejiendo redes. La emergencia del liderazgo de Callfucurá a fines del período rosista", El liderazgo indígena en los espacios fronterizos americanos (siglos XVIII y XIX), Buenos Aires, Museo Etnográfico Juan B. Ambrosetti, 2007.

Salvatore, Ricardo, "El imperio de la ley. Delito, estado y sociedad en la era rosista", Delito y Sociedad. Revista de Ciencias Sociales, 3/4 y 5 (Buenos Aires, 1993-94), 93-118.

Salvatore, Ricardo, Wandering paysanos State order and subaltern experience in Buenos Aires during the Rosas era, Durham and London, Duke University Press, 2003.

Villar, Daniel y Jiménez, Juan Francisco, "La tempestad de la guerra: conflictos indígenas y circuitos de intercambio. Elementos para una periodización (Araucanía y las pampas, 1780-1840)", Raúl Mandrini y Carlos D. Paz (comps.), Las Fronteras Hispanocriollas del Mundo Indígena Latinoamericano en los Siglos XVIII-XIX. Un estudio comparativo, Tandil, IHES-UNCPBA / CEHIR-UNCo / UNSur, 2003: 123-171.

Weber, David, "Borbones y bárbaros. Centro y periferia en la reformulación de la política de España hacia los indígenas no sometidos", Anuario del IEHS, TandilUniversidad Nacional del Centro de la Provincia de Buenos Aires, 13 (Tandil, 1998): 147-172. 
Weber, David, Barbaros. Spaniards and their savages in the age of enlightment, New Haven y Londres, Yale University Press, 2005.

Zeballos, Estanislao, "Callfucurá y la Dinastía de los Piedra”, Callfucurá, Painé, Relmú, Buenos Aires, Elefante Blanco, 2007.

\section{Fuentes EDITADAS}

Arnold, Prudencio, Un soldado argentino, Buenos Aires, Eudeba, 1970.

Avendaño, Santiago (recopilación del P. Meinrado Hux), Usos y costumbres de los indios de la pampa, Buenos Aires, Elefante Blanco, 2000.

Darwin, Charles, Diario del viaje de un naturalista alrededor del mundo (en el navio de S. M. Beagle), elaleph.com, 2000.

Guevara Silva, Tomás, Historia de la civilización de Araucanía, Santiago de Chile, 1898, vol. III.

Mc Cann, William, Viaje a caballo por las provincias argentinas, Buenos Aires, Hyspamérica, 1985.

Fecha de recepción: 21/03/2011

Fecha de aceptación: 11/07/2011

\section{Between reparations and punishment. Actions taken by the authorities of Buenos Aires in order to tackle thefts committed by the friendly indians in the rural area (1832-1855)}

This piece of work intends to show the impact produced by the «porteña» politics among the Indians, who we have already mentioned, giving special emphasis to the attempts taken to eliminating or reducing indian theft. Thus, the following pages, will show how two ways were found in order to conceive and solve one same problem. If the friendly indians associated theft with the damage caused to a member of a group by another one, and which therefore required reparation, the provincial authorities considered it an infringement of the law.

Key words: Juan Manuel de Rosas; Provincial Authorities; Friendly Indians; Thefts; Punishment. 